\title{
Seaweed Aquaculture in Indonesia Contributes to Social and Economic Aspects of Livelihoods and Community Wellbeing
}

\author{
Michael A. Rimmer ${ }^{1, *}\left(\mathbb{D}\right.$, Silva Larson ${ }^{1}$ (), Imran Lapong ${ }^{2}$, Agus Heri Purnomo ${ }^{3}$, Petrus Rani Pong-Masak ${ }^{4}$, \\ Libby Swanepoel ${ }^{5}\left(\mathbb{D}\right.$ and Nicholas A. Paul ${ }^{1}[$
}

1 School of Science, Technology and Engineering, University of the Sunshine Coast, Sippy Downs, QLD 4556, Australia; silva.larson@gmail.com (S.L.); npaul@usc.edu.au (N.A.P.)

2 Department of Aquaculture, Institut Teknologi dan Bisnis Maritim Balikdiwa, Tamalanrea, Makassar 90245, Indonesia; lapong.mula@gmail.com

3 Research Centre for Marine Fisheries Socioeconomics, Ministry of Marine Affairs and Fisheries, Jakarta 14430, Indonesia; a_heri_p@yahoo.com

4 Research Institute for Seaweed Culture, Ministry of Marine Affairs and Fisheries, Mananggu, Boalemo 96265, Indonesia; pg_masak@yahoo.com

5 School of Health and Behavioural Sciences, University of the Sunshine Coast, Sippy Downs, QLD 4556, Australia; lswanepo@usc.edu.au

* Correspondence: mrimmer@usc.edu.au

Citation: Rimmer, M.A.; Larson, S.; Lapong, I.; Purnomo, A.H.; Pong-Masak, P.R.; Swanepoel, L.; Paul, N.A. Seaweed Aquaculture in Indonesia Contributes to Social and Economic Aspects of Livelihoods and Community Wellbeing. Sustainability 2021, 13, 10946. https://doi.org/ $10.3390 /$ su131910946

Academic Editors: Susan Gibson-Kueh, Caryn West and Jacob Wood

Received: 24 July 2021

Accepted: 27 September 2021

Published: 1 October 2021

Publisher's Note: MDPI stays neutral with regard to jurisdictional claims in published maps and institutional affiliations.

Copyright: (c) 2021 by the authors. Licensee MDPI, Basel, Switzerland. This article is an open access article distributed under the terms and conditions of the Creative Commons Attribution (CC BY) license (https:// creativecommons.org/licenses/by/ $4.0 /)$.

\begin{abstract}
Seaweed farming in Indonesia is carried out throughout much of the archipelago and is mainly undertaken by smallholder farmers. Indonesia is the largest global producer of the red seaweeds Kappaphycus and Eucheuma, which are used to produce carrageenan, and is a major producer of Gracilaria, which is used to produce agar. Seaweed farming is attractive to farmers in rural coastal communities because capital and operating costs are low, farming techniques are not technically demanding, labour requirements are relatively low (allowing farmers to engage in other livelihoods), and production cycles are short (30-45 days), providing regular income. Using reported values for seaweed-farming income, we conclude that seaweed farming can, but does not always, lift rural households above the Indonesian poverty line. In addition to direct financial benefits, seaweed farming also contributes to human and social capital within seaweed farming households and communities. Achieving continued economic and social benefits from seaweed farming will require additional policy development, as well as research and development to support improved and more consistent seaweed productivity and improved product quality at the farm level, provision of effective extension and technical support services, and diversification of the existing value chains in order to reduce the impacts of price fluctuations that are associated with limited global commodity chains.
\end{abstract}

Keywords: seaweed; livelihoods; aquaculture; Indonesia; value chain

\section{Introduction}

Seaweeds are directly consumed in Asia, in parts of South America and in the Pacific Islands [1-3], and there is increasing interest in their role in supporting human health as nutraceuticals or functional foods [4,5]. However, about $99 \%$ of farmed seaweed is used for the production of thickening and gelling agents for the pharmaceutical and food industries [1]. Indonesia is a significant contributor to global seaweed production, particularly the red seaweeds Kappaphycus alvarezii (hereafter Kappaphycus) and Eucheuma denticulatum (hereafter Eucheuma), which are used to produce carrageenan, and Gracilaria species, which are used to produce agar. In around 2005, Indonesia surpassed the Philippines as the dominant producer of the carrageenan-yielding Eucheumatoid seaweeds [6,7] and by 2015 Indonesia was producing $65 \%$ of the global total of Kappaphycus and $56 \%$ of the global total of Eucheuma [8]. At the national policy level, aquaculture is expected to play a major role as a pillar of the economy and in supporting national food security and nutrition $[9,10]$. To 
support this objective, a national roadmap for seaweed industry development was created for 2018-2021 to boost economic growth and social empowerment (Presidential Regulation No. 33/2019; Table 1).

World seaweed prices fluctuate considerably from year to year, and even from one production cycle to the next. For example, the farm-gate price paid for Kappaphycus per tonne of dry product (i.e., $<38 \%$ moisture [11]) in Indonesia in 2007 was USD 811, but in 2008, the farm-gate price more than doubled to USD 2166 per tonne dry weight. In 2009, the farm-gate price then dropped to USD 1208 per tonne dry weight [12]. More recently the farm-gate prices in Indonesia appear to have stabilised at between USD 550 and 750 per tonne dry weight (http:/ / www.jasuda.net/, accessed 4 September 2020), before declining again due to COVID-19 impacts on trade [13]. The price paid for seaweed in Indonesia appears to be in line with the seaweed prices typically paid by China [12], and lower than average world prices. In response to these cycles, seaweed farmers often move between seaweed farming and other livelihood activities, such as fishing [10]. Importantly, seaweed farming is still perceived by local communities who engage in this practice to be a major contributor to wellbeing and livelihoods [14].

As increasing population density and fishing pressures have created a need for alternative sources of income, seaweed farming provides an opportunity in remote areas where coastal communities face a limited number of economic alternatives [11]. The key advantages for the proliferation of seaweed farming are likely to be low investment, relatively simple culture techniques, regular income and profitability [11]. Additional incomes associated with seaweed farming have created a level of financial resilience, increasing communities' capacity to adapt while decreasing their dependence on limited resources (historically, capture fisheries). In this paper we argue that, over time, financial betterments have precipitated wider economic benefits (e.g., the ability to improve education/job prospects; seed capital for additional businesses, resulting in further diversification of incomes and long-term livelihoods security, etc.); which, in turn, have built the capacity of communities to adapt to change and maintain function [15-18].

Seaweed farming also provides an important livelihood diversification option in times of extreme economic disruption and, as such, acts as a mechanism to improve resilience in coastal communities. At Nusa Lembongan, Bali, seaweed farming declined dramatically over the period 2012-2017 as seaweed farmers moved to employment in Bali's burgeoning tourisms industry or in construction (which was also associated with tourism development) [19]. With the temporary collapse of tourism in 2017 associated with the eruption of the Gunung Agung volcano, there was a resurgence in seaweed farming at Nusa Lembongan [19]. A similar recent resurgence of seaweed farming has been reported as a direct outcome of the collapse of tourism in Bali resulting from the COVID-19 pandemic [20]. In South Sulawesi, seaweed production has increased markedly since mid-2020, despite lower farm-gate prices, apparently due to the reduced employment opportunities associated with COVID-19 impacts on the economy and employment opportunities [13].

In this review we evaluate the potential for seaweed farming to contribute sustainably to improved and more resilient livelihoods for people in the tropics, based on the evidence from Indonesia. This evidence is evaluated in the context of a sustainability science approach to Indonesian seaweed farming, which provides a framework to assess the sustainability of either individual aquaculture industries or production systems incorporating: (i) definition of sustainability issues; (ii) sustainability assessment; (iii) detailed risk analysis; (iv) plan to ameliorate identified impacts; and (v) plan for communicating the evolution of operations towards greater stewardship and sustainability [21]. In adopting this approach, we note that there are several recently-published reviews of the environmental aspects of tropical seaweed aquaculture [22-27], as well as seaweed farming more broadly, including the provision of ecosystem services [28-32]. Rather than repeat the conclusions of these reviews, in this paper we augment the scientific literature's focus on the environmental aspects of tropical seaweed mariculture by focusing on social and economic aspects. 
In taking this approach we explore the potential of seaweed aquaculture to contribute to improved and more resilient livelihoods and the wellbeing of people in the tropics, with a specific focus on Indonesia. We do so by introducing the seaweed farming value chains in Indonesia, examining the economic and social costs and benefits associated with seaweed farming in Indonesia and summarizing the risks to seaweed farmers related to production factors and market chains. We conclude the paper with a summary of Indonesian legislation and regulations relevant to seaweed farming and policy recommendations that could support improved economic and social outcomes for Indonesian seaweed farmers.

\section{Seaweed Farming and Value Chains}

Carrageenophyte seaweeds were originally introduced to Indonesia from the Philippines and are now widely cultivated throughout the archipelago [6-8,33]. Some local cultivars of Kappaphycus may also be cultured, but the origin of most cultivars is now obscure [6]. A study of farmed seaweed from 14 locations across Indonesia showed that all of the samples from floating line cultures were K. alvarezii and that these showed very limited genetic variation, presumably due to the use of clonal propagation methods by famers and harvest prior to sexual reproduction $[8,34]$. The same study found one sample of Kappaphycus striatus from bottom-line cultivation [34]. Although tissue-culture cultivars of K. alvarezii have been developed [35], these have not yet seen widespread uptake by commercial farmers.

Production and value data, as reported to FAO, for Indonesian seaweed production indicate that production is dominated by what is categorized in the data as Eucheuma ('Eucheuma seaweeds nei [not elsewhere included]') (Figure 1), but, in fact, this category comprises both carrageenophyte seaweeds, Kappaphycus and Eucheuma. In many parts of Indonesia seaweed has become a leading commodity cultivated by coastal communities, with reported production effectively doubling between 2011 and 2016 [9]. Over the past two decades production increased annually before peaking in 2014 , after which production began to decline slightly (Figure 1). However, a recent survey of seaweed production in South Sulawesi, conducted using remote sensing, concluded that official production statistics are gross over-estimates of actual production [13], and this has also been expressed anecdotally to the authors by Indonesian seaweed processors. Note that some of the discrepancies in reported production can be attributed to differences in the reporting metric (wet or dry weight), which should be clarified to avoid confusion.
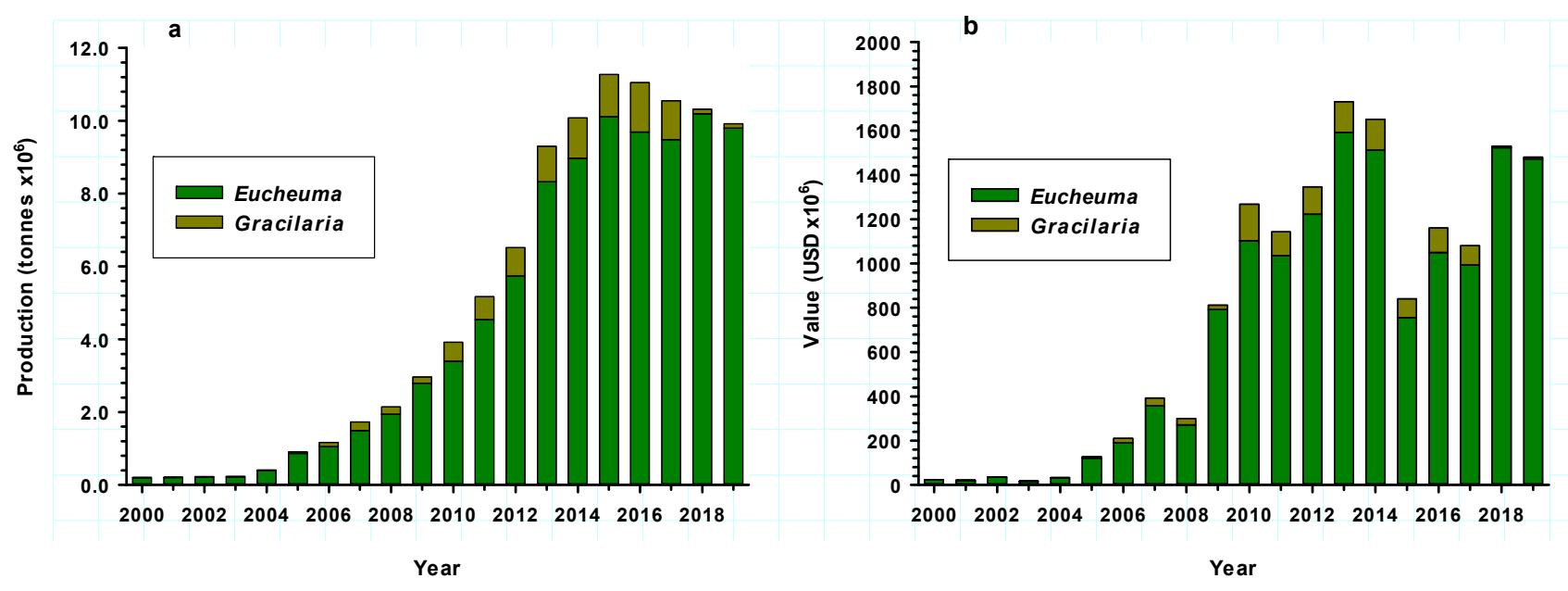

Figure 1. Annual (a) production (wet weight) and (b) value of production of seaweeds from Indonesia from 2000 to 2019. Data from FAO [36]; note that 2018 and 2019 data are estimates only.

Two key features of seaweed production in Indonesia relate to its scale and scope. The first key feature is that farming is carried out over a substantial area of the archipelago. Figure 2 shows province-level production for the provinces where 2019 production was $>0.1 \%$ 
of the national total. This map shows that seaweed farming is undertaken in much of the Indonesian archipelago, ranging from West Java through to Maluku and East Nusa Tenggara provinces in the east (Figure 2). In 2019 there was also some small production from Sumatra Island (total 9232 tonnes wet weight), Bali (850 tonnes wet weight) and Papua (Papua and West Papua provinces total 2575 tonnes wet weight), indicating that there is some level of production from all of the major islands in the archipelago.

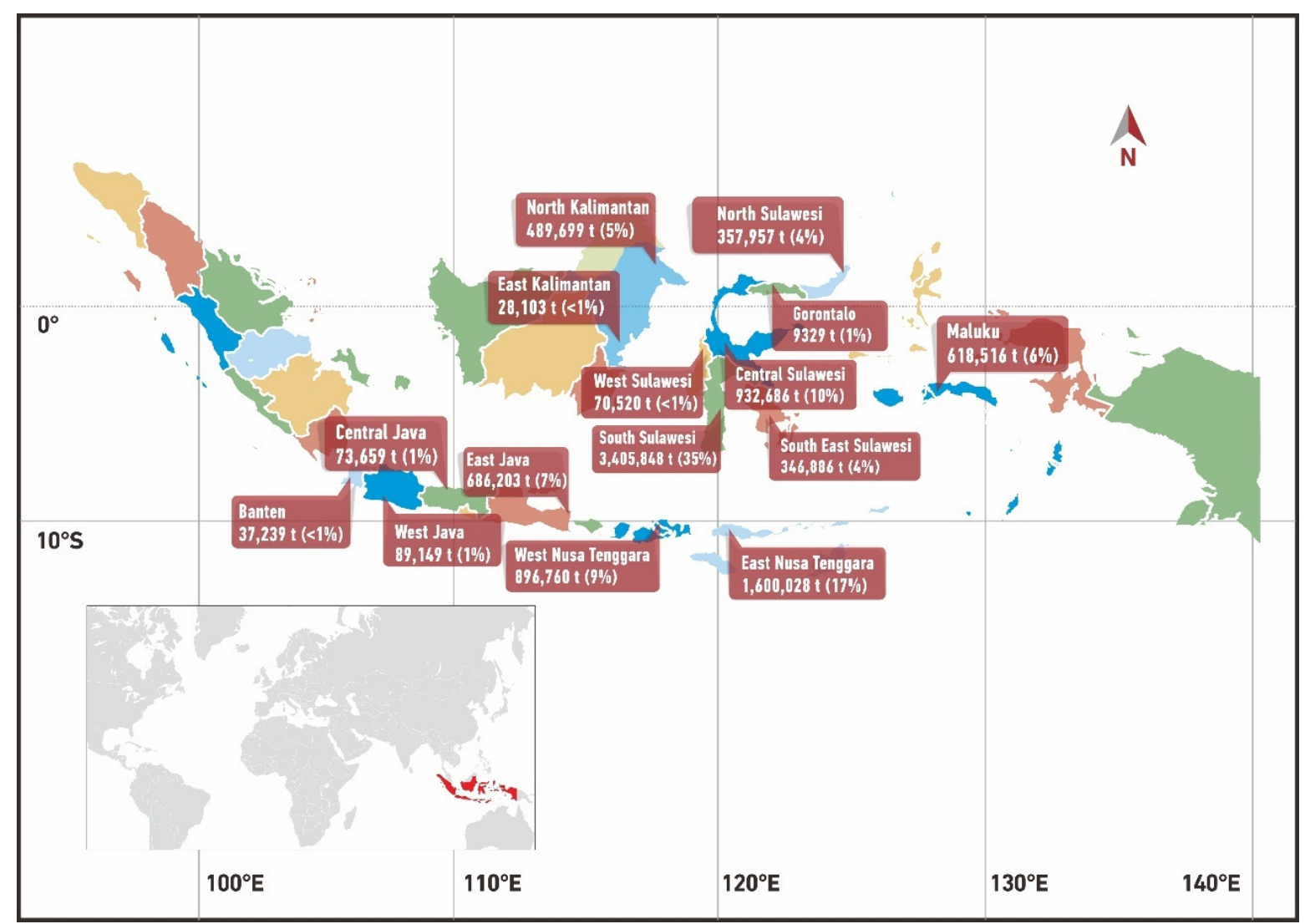

Figure 2. Map of Indonesia showing 2019 province-level seaweed production in tonnes (wet weight), and as proportion of total national volume of production. Data source: https://statistik.kkp.go.id, 2019 data for seaweed, accessed 8 February 2021. Note that the different seaweed types are not differentiated in this data set. Provinces producing $<0.1 \%$ of the national total were omitted from the map. NT: Nusa Tenggara.

The second key feature of seaweed production in Indonesia is the involvement of large numbers of smallholder farmers. An estimated 267,000 households benefit from seaweed farming in Indonesia [13], with the average mariculture farm size varying from about 0.1 ha in Bali to 1.0 ha in South Sulawesi [11]. Most (78\%) brackishwater pond farms surveyed in Takalar Regency, South Sulawesi, had less than 1 ha of pond area each [37]. The production systems used for seaweed (either mariculture or brackishwater ponds) are accessible to smallholder farmers because of their relatively low establishment and operational costs, simple production system, short production cycle, and the cultural acceptability of the practice.

The ease of cultivation of Kappaphycus and Eucheuma seaweeds is a major factor in allowing seaweed farming on small-scale or family-operated farms in remote areas. Seedstock production can be done by farmers, using vegetative propagation methods in nearshore systems that are accessible by small vessels or even on foot at low tide. Seaweed propagules (small clumps of seaweed from the previous harvest) are tied to the main lines with short lengths of string ('tie-ties') at about $20 \mathrm{~cm}$ intervals [6]. 'Tying-on' is done onshore, and typically involves female labour [14]. After the propagules are tied on, the lines are returned to the sea and tended daily or every few days to check growth and 
predation of the seaweed and to remove biofouling. A typical culture cycle is about 45 days, after which the seaweed lines are brought ashore, the seaweed harvested, new propagules tied on, and the culture process repeated.

Seaweed farming in Indonesia comprises three main value chains. The first is mariculture (farming in the sea) of the carrageenophytes Kappaphycus and Eucheuma in shallow coastal areas, particularly sheltered bays. Kappaphycus and Eucheuma respectively provide kappa and iota carrageenans, which are used in food products as gelling, thickening, and stabilising agents, as well as in experimental medicine, pharmaceutical formulations, cosmetics, and industrial applications [38]. A variety of culture methods, including rafts and arrays of long-lines, have been used for farming Kappaphycus and Eucheuma [6]. After harvesting, Kappaphycus and Eucheuma are dried onshore on the ground or on racks and then sold to middlemen for processing, either in Indonesia or offshore [11].

The second major value chain is for the agarophyte Gracilaria, which is the preferred seaweed for making agar which is used in a variety of food and medical processes [39-41]. In 2015, Indonesia and China together produced 69\% of the world total of agar [8]. Most Gracilaria culture is undertaken in brackishwater ponds, usually in polyculture with milkfish (Chanos chanos), shrimp or other euryhaline species [42-45]. There is some culture of Gracilaria using long-line techniques in shallow coastal waters of Takalar Regency, South Sulawesi [46]. Gracilaria cultured in ponds produces agar of a lower gel strength than wild collected seaweed, and reportedly lower than maricultured seaweed, and thus brings prices toward the bottom range for food agar [40]. Harvested Gracilaria is dried on pond banks or adjacent roadways, and is then sold for processing into agar [11,43].

A third value chain is the marketing of seaweed and seaweed-based products at the local markets for human consumption. This includes the edible seaweed Caulerpa, which is cultured in coastal ponds [47,48]. In South Sulawesi and some other parts of Indonesia, Caulerpa is sold directly to local markets and used as a salad vegetable [48,49]. Local markets also sell dried Kappaphycus and Eucheuma which are purchased by consumers who rehydrate these dried seaweeds for use in their own dishes and for cooking at home, and in some areas markets also sell a range of seaweed-based 'snack' products [14].

\section{Costs and Benefits Associated with Seaweed Farming}

\subsection{Production Costs Are Low}

Capital and operating costs for seaweed production are relatively low $[11,50,51]$. The costs to establish a one kilometre array of seaweed farming lines was estimated at around USD 107.50, with the material having a 2-year lifespan [11]. Seaweed cuttings to establish the cultures was estimated at an additional USD 192 per $\mathrm{km}$ of lines. A 'nuclear farm' (typically, about a $6 \mathrm{~km}$ array of lines) requires additional equipment, such as boats, shelter and drying facilities, and sacks for packing, which total USD 1016. For a 'leader farm' (30 km of lines), the similar but larger facilities cost a total USD 3864 to establish [11]. Shelters and drying racks are commonly shared amongst individuals and may be used for other economic activities, such as drying fish or agriculture products [11]. Similarly, boats used for seaweed farming may be used for fishing or transport [11,50]. The average capital cost for a seaweed farm in Takalar Regency, South Sulawesi, was estimated to be IDR 8,300,000 (ca. USD 590-USD are calculated based on a nominal exchange rate of IDR $14,000=\mathrm{USD} 1.00$.), and the estimated payback period for this investment was estimated to be a little over three months [52]. This amount was used to purchase aquaculture infrastructure (main ropes, small ropes, and buoys), seaweed seeds and for payment of operational costs. The main operational cost was seeding (tying on of new propagules), accounting for $28 \%$ of variable costs [52]. Revenue:cost (R/C) ratios for seaweed farming reportedly range from 1.5 to 2.6 in South Sulawesi [53], from 0.96 to 21.0 in Southeast Sulawesi [51], and from 3.3 to 3.4 in Maluku [54].

The production cycle is short, typically 45 days from planting to harvest for Kappaphycus [11,50], with a similar production cycle duration for Gracilaria [37]. This short production cycle allows for a quick return on investment and a regular income to the 
farmer. Kappaphycus farm productivity ranges from 6 tonnes/ha in South Sulawesi to almost 60 tonnes/ha in Bali, with the higher productivity of the Balinese farms apparently due to closer spacing of the culture lines [11].

All aspects of the production cycle, including the production of seedstock, are simple and can be done either on the farm (cleaning the seaweed lines, harvesting) or onshore in the village (removing the seaweed from the culture lines at harvest, and tying on of new explants) [13]. Culture methods used by Indonesian seaweed farmers vary, but are all based on simple and cheap technologies and materials [6]. Seaweed farming and drying are not technologically demanding types of production, and the knowledge required spreads quickly from farmers with the experience to new farmers, without the need for formal training or extension [6].

Seaweed farming is also not very labour intensive. The main task is that of attaching cuttings to lines, with placing and removing lines to/from sea and drying the crop also noted as significant tasks. This work is performed either by family members, in cooperation with other farmers, or by paid labour and is estimated to cost approximately USD 144 per $\mathrm{km}$ of line [11]. The low labour cost indicates that, even when work is performed by family members, it is not burdensome and leaves time for other income generating activities.

One of the main potential negative personal and social effects of seaweed farming reported in the international literature are health impacts $[55,56]$. In contrast, a wellbeing study in Indonesia found no evidence of negative health impacts from seaweed farming [14]. In addition, women reported no negative impacts from additional income, such as spending on social ills or increases in family violence [14] and no evidence of marital discontent as a result of financial distributions [11].

Environmental costs of seaweed farming are also reported in the international literature, in particular, the impacts on seagrass habitats due to shading or trampling are emphasised [22,24,26]. However, a study undertaken in Takalar Regency in South Sulawesi concluded that the current culture methods of seaweed farming in the region do not interfere with the seagrass flora and that reduction of habitat quality for the associated fauna was minimal [57]. For some other forms of seaweed farming the damage has already been done; for example, many of the coastal ponds now used for polyculture with Gracilaria were originally constructed for shrimp or milkfish culture and involved a considerable loss of mangrove habitat [44]. Seaweed farming can have positive environmental impacts, since it is often associated with reductions in some types of fishing [57], is associated with increased catches of herbivorous fish species [25], and seaweed farms demonstrate higher abundance and greater species richness of wild, mobile macrofauna than unfarmed areas [58].

\subsection{Economic Benefits Are Variable, but Generally Positive}

Revenue from seaweed farming varies substantially, not just between farms, but also seasonally [11,59]. Farm productivity is influenced by farming methods, seasonal variations in productivity, local environmental conditions, and the specific seaweed cultivar used on the farm $[11,59,60]$. For example, monthly income from seaweed farming in Rote Island (East Nusa Tenggara province) increased from an average of USD 62 during the dry season to USD 94 during the rainy season [59].

In addition to farm productivity, revenue is strongly influenced by the commodity price for seaweed at the time of sale [11]. For example, the average South Sulawesi farm production could generate annual gross revenues ranging from USD 3200 for a low price (at a farm-gate price of USD 500/tonne dry weight) to USD 7600 for a high price (farm-gate price USD 1200/tonne dry weight) [11]. Economic data on brackishwater seaweed farming is limited, and is presented in Appendix A.

To examine the potential for seaweed aquaculture to directly support households at income levels above the poverty line, we evaluated reported income levels from several studies of seaweed farming in Indonesia, mostly from the period 2018-2019, which are 
the most recent economic evaluations available and predate the decline in seaweed prices associated with the COVID-19 pandemic, despite lower farm-gate prices [13]. We also include data from Neish's [11] more extensive 2013 report for comparison (Figure 3). Reports of profitability for seaweed mariculture farms vary widely, from an average of IDR 10.6 million (USD 760) per annum in Southeast Sulawesi [51], from IDR 16.9 to 37.8 million (USD 1200-2700) per cycle across four districts in South Sulawesi [53], and from IDR 15.1 million (USD 1080) per annum for small seaweed farms $(10 \mathrm{~m} \times 25 \mathrm{~m})$ up to IDR 29.9 million (USD 2135) per annum for large farms $(10 \mathrm{~m} \times 50 \mathrm{~m})$ in Tual, Maluku [54]. A survey in Bombana District of Southeast Sulawesi found that the annual income from seaweed farming ranged from IDR 3.6 million (USD 257) to IDR 18.5 million (USD 1321), and that $92 \%$ of farmers earned an annual income between IDR 3.6 million (USD 257) and IDR 15.8 million (USD 1129) [61]. For reference, the September 2018 national rural poverty line in Indonesia was equivalent to IDR 4.7 million (USD 336) per annum per capita [62]. We have calculated a household national rural poverty value for a five-person household, based on the method of Valderrama et al. [63] and reflecting the socio-economic data of two of the studies cited above [51,59] at USD 1680 (Figure 3). Graphing the various income estimates for seaweed farming against this household poverty line (Figure 3) indicates that, while seaweed farming income can bring families out of poverty, this is by no means always the case. Seaweed farming income in three reported studies, two in Southeast Sulawesi [51,61] and one in Rote Island [59], all fall below the poverty reference level (Figure 3).

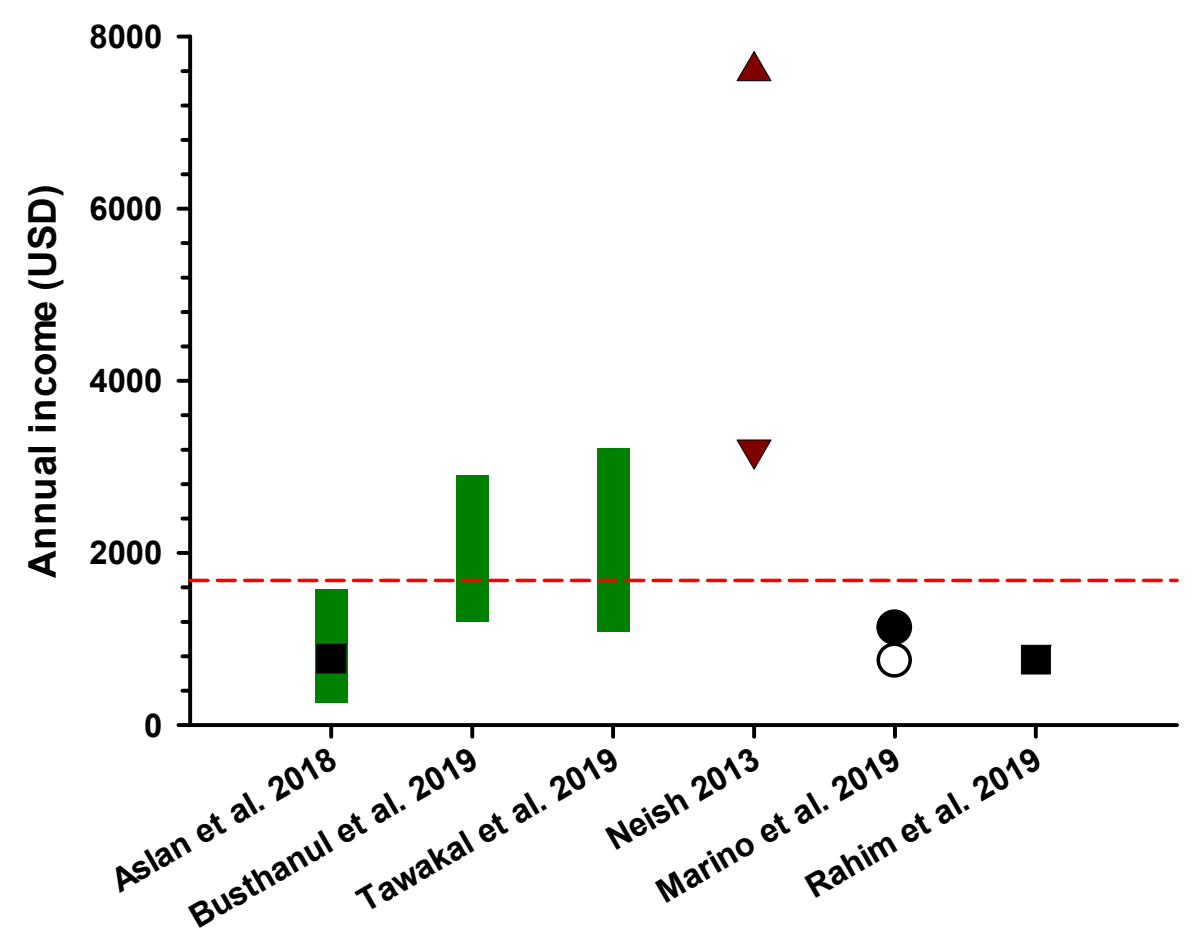

\section{Source}

Figure 3. Published estimates of income generated by seaweed mariculture in Indonesia as reported in the cited publications. Green bars indicate the range of values; black squares indicate average values; triangles indicate average values for low $(\boldsymbol{\nabla})$ and high $(\boldsymbol{\Delta})$ commodity prices respectively; and for dry season $(\bigcirc)$ and wet season $(\bullet)$ production. The data in Busthanul et al. 2019 [53] are originally per production cycle and we have assumed four cycles per annum to estimate annual income. The dashed red line represents the September 2018 national rural poverty line for Indonesia [62] calculated for a five-person household. 
When considering rural poverty estimates, it is important to note that most farmers do not engage in seaweed processing as a full-time activity. As seaweed farming is not very labour intensive, it leaves time for family members to engage in alternative incomegenerating activities. Income diversification is an important and common coping practice in rural situations where engagement with any single income source is risky [64], and the key element of livelihood strategies is efficient use of family labour, within or beyond the farm [65]. Most seaweed farmers in studies in Indonesia report diversified sources of income. Of 74 women in nine seaweed farming villages of Takalar Regency, South Sulawesi, $54 \%$ reported seaweed farming as an important household activity, and 37\% of women reported seaweed farming as the main household activity, generating $50 \%$ or more of their household income [14]. The remaining participants came from households primarily engaged in agriculture, fishing and fish aquaculture or with small businesses. Another survey of 30 seaweed farmers in the same Regency found that $46 \%$ of their income came from rice culture, 32\% from seaweed farming and the remainder from 'non-rice agriculture' and 'non-agriculture' sources [66]. In Laikang Bay, Takalar Regency, fishermen rely on a variety of livelihood activities, including capture fisheries, seaweed farming, public services employment, and other non-fishing activities [67]. Forty-six percent of Laikang Bay seaweed farmers conducted seaweed farming as their sole economic activity, while other farmers (37\%) combined seaweed farming with fishing [67].

Access to non-agricultural employment can significantly boost household income. Seaweed-farming households on Rote Island who had access to additional income sources had a higher overall income than those that exclusively farmed seaweed [59]. While income derived from agriculture and animal husbandry was low (USD 2-40/month), income from employment in hotels (USD 165-263/month) and in construction or private security (USD 10-220/month) was often greater than the income earned from seaweed farming (average USD 62-94/month) [59]. Although many seaweed farmers are also fishers, income from fishing is often relatively small. In South Konawe District, Southeast Sulawesi, a survey of 96 households found that only 12\% of income came from capture fishing (including 'bagan' lift nets and crab trapping), while 36\% of income was from seaweed farming, and $38 \%$ from non-fishery sources (e.g., shops, labouring, boat driving, terrestrial agriculture), despite only $14 \%$ of respondents being involved in non-fishery activities [51]. Similarly, a study in Bombana District, Southeast Sulawesi, found that the average annual income from fishing was IDR 1.4 million (USD 103), with 70\% of fishers earning less than IDR 1.5 million (USD 107) per annum, compared to income from seaweed farming of IDR 3.6-18.5 million (USD 257-1321) [61].

\subsection{Personal and Social Benefits Are Regarded Positively}

Wellbeing and life satisfaction literature explore methods that allow for investigations of impacts of policy changes or development interventions, beyond mere income estimates. Such methods are becoming an increasingly important tool in international development, planning and management [68-72], as well as fisheries and aquaculture management [14,73-76]. Human wellbeing consists of various dimensions, and, in addition to economic factors, self-esteem, social and environmental factors also play important roles [77-79]. As a holistic concept, wellbeing consists of both subjective and objective dimensions relating to people's overall quality of life and the factors affecting it [77]. Subjective elements indicate how a condition is perceived by participants, and is distinct from an objective and independently observable assessment of conditions [73]. Subjective wellbeing is frequently measured by asking people to respond to questions about their satisfaction with life overall and with the various factors that are likely to influence it. The approach takes into account individual experiences and helps to understand and communicate the interpretations, priorities and needs of people [80,81]. Numerous empirical applications of the approach worldwide have shown that complex and intangible impacts of change which cannot be measured in monetary terms are often just as significant to human wellbeing as the more tangible, and often monetary, impacts; perhaps even more so [82]. 
In several studies, farmers from the major farming region of South Sulawesi indicated that the social as well as economic impacts of seaweed farming on their coastal communities have been positive $[11,12,48,57]$. An important aspects of seaweed farming is that it is that it is perceived as complementary to and compatible with other village activities, such as fishing and terrestrial agriculture, as well as with the existing village norms, rules and structures [11]. A study that examined perceived changes in lifestyles upon adoption of seaweed farming in North Sulawesi, found that $73 \%$ of participating farmers specifically said that their lives were better as a result of seaweed farming [83].

Two studies in South Sulawesi investigated the impacts of participation in seaweed farming and artisanal seaweed processing in relation to a range of potential financial, personal, social and environmental benefits $[14,84]$. These studies used a well-being-impact evaluation (W-IE) method [85], asking respondents to (a) identify and rate wellbeing factors that are important to their wellbeing; (b) provide a rating of their satisfaction with those factors at the time of the study and five years prior; and (c) describe what, in their view, has caused the change in satisfaction (if any). In this method, qualitative responses to questions about perceived changes and the causes of change are then linked to quantitative data to draw inferences about the existence and/or importance of impact(s). Surveying 74 women from coastal villages where seaweed is a significant source of household income, studies found evidence of positive economic and social impacts from seaweed farming. Five of the ten contributors to participants' wellbeing which were self-selected as the most important (the ability to purchase or renovate a house, purchase of a motorbike, financing children's higher education, and fulfilment of basic and secondary needs) were reported as being directly and positively impacted by seaweed farming. In terms of social benefits, social networks played a particularly important role, being selected as an important contributor to wellbeing by more than $30 \%$ of respondents. Other personal and social benefits reported in relation to seaweed farming and artisanal processing of seaweed included: sharing experiences and learning new skills; having good role models in the community; having jobs that people enjoy doing, not just jobs for money; having a job in the local village (local job); and the pride from owning a business [84]. Increased life satisfaction was reported throughout participating villages, both by women from families engaged in seaweed farming and those who were not, suggesting that the benefits of seaweed farming are perceived as being spread reasonably equitably through the entire community and that non-participant households, as well as participants, benefit from seaweed farming-generated income [14].

\subsection{Seaweeds Contribute to Human Health}

Seaweeds are a rich source of micronutrients, fibre and bioactive compounds, offering promising health benefits. The micro-nutritional and sensory benefits of seaweeds as wholefoods or functional foods are acknowledged but not well understood due to variation across species and coastal environments, and a lack of scientific evidence regarding nutritional bioavailability and human metabolism [2]. Despite efforts in developing new products, not many have utilized seaweed nutraceuticals for human health and wellbeing, because of the pre-requisite human trials and nutritional intervention studies [86]. There is, however, still increasing commercial demand for seaweed products owing to a consumer focus on health and functional foods [87]. Coastal communities in the Pacific Islands, for example, report health as a motivator for seaweed consumption [88], noting the importance of easy access to the natural resource and the use of seaweed in traditional events or ceremonies [3]. The seaweeds utilised by remote coastal communities are typically wild-harvested and generally of much higher diversity than that which is accessible from seaweed farming in the major production areas.

Seaweed farming families in South Sulawesi have concentrated on producing seaweedbased food products for domestic and international markets, exclusively with farmed seaweed. A variety of products are made, such as crackers, noodles, 'bakso', candy and ice cream, from Kappaphycus, brownies from Eucheuma, and 'sangosango' from Gracilaria. 
Nutrient analysis of these product recipes, based on the nutrient content of raw ingredients adjusted by retention factors, reveals that the addition of seaweed improves the nutrient density of common recipes, contributing to recommended nutrient intakes. The addition of seaweed in these food products also results in a favourable sodium:potassium ratio, which aligns with dietary recommendations to reduce blood pressure and counteract hypertension [89-91]. Further studies that establish the bioavailability of seaweed bioactives are needed to understand the therapeutic development of seaweed-based functional food products.

Smallholder farmers may see direct benefits to food and nutrition security through household consumption of their produce and related dietary improvement. Caulerpa and, to a lesser extent, Gracilaria are consumed in salads or as side-dishes as part of a main meal [48,49]. Kappaphycus and Eucheuma are generally dried and then rehydrated after purchase to incorporate into home-cooked dishes or in 'snack' products [14]. More broadly, aquaculture farmers also see indirect benefits through the sale of farmed produce to purchase other food items at a cheaper price [92] and this is likely to be the case for seaweed farmers. Further analysis of seaweed distribution patterns across social and market networks will provide a greater understanding of seaweed commodity-flows and identify potential entry points to support improved food and nutrition security.

\section{Risk Assessment for Smallholder Seaweed Farmers}

In this section we analyse the risks to seaweed farming in Indonesia from a sustainability science perspective [21], incorporating environmental, economic and social aspects. We categorise these risks as production risks (i.e., those directly impacting farms and farming households) and risk associated with markets and the seaweed farming value chain.

\subsection{Production Risks}

Seaweed mariculture farmers commonly cite seasonal and locational factors as causing variation in seaweed production [11]. There appears to be a complex interaction of location and climate, with some farmers reporting good seaweed farming during the rainy season and others reporting good productivity during the dry season [11]. A study of seaweed production in South Sulawesi using remote sensing showed distinct and substantial monthly variations in production, with this being linked to rainfall patterns [13]. Indonesian seaweed farmers respond to these seasonal and locational variations in productivity by shifting to another farming site (many farmers have more than one site available to them), by changing from culturing Kappaphycus to the more resilient but lower-value Eucheuma, or both [11].

These seasonal trends are also reflected in material export data. A distinct seasonal pattern was identified for seaweed exports from Indonesia during the period 2000-2008, which apparently reflects the overall seasonality of production [11]. The first quarter of each year was usually the season with the lowest amount of product exported ( $20 \%$ of the annual export), followed by the second quarter $(24 \%)$, the third quarter $(28 \%)$ with the highest amount of seaweed product exported in the fourth quarter (29\%) [11].

In addition to seasonal variation, there is substantial variation between locations, even at small spatial scales, i.e., a few kilometres [11]. Productivity between farming sites in Indonesia (evaluated using identical farming methods in different locations at the same time) can vary by a factor of five (i.e., $600 \%$ difference), and this variation can be ascribed to local environmental conditions, as well as the seaweed cultivar used [60].

Several long-term productivity risks to seaweed cultivation have been identified. Since about 1970 there has been a steady decline in hardiness and carrageenan quality of cultivated seaweed [33] and over the period 2000-2015 there has been a decline in carrageenan yield from both Kappaphycus and Eucheuma of around 15\%, equivalent to 1\% per annum [8]. This decline is likely due to the mode of vegetative reproduction used by farmers to generate seedstock. Because the plants are harvested before they reach a level of maturity where they may reproduce sexually, this may result in the stocks having a 
limited ability to adapt to changing environmental conditions in farming areas [8]. There are also anecdotal reports of differences in growth relating to the initial propagule weight (for example, from $20 \mathrm{~g}$ up to $>100 \mathrm{~g}$ ), with farmers sometimes choosing to spread the seedstock out, hence reducing the biomass of individual seedlings, to maximise the number of propagules. A value of $50 \mathrm{~g}$ is cited as a preferred propagule weight [60].

Like other forms of aquaculture, seaweed farming is adversely affected by a range of pests and diseases. A recent review of diseases found in seaweed farming in Asia noted the need for better categorisation of the causes of production losses in seaweed farms, and the development of improved mitigation strategies for dealing with disease outbreaks [93]. As in other areas of aquaculture, the frequency and extent of disease outbreaks can be reduced by implementing effective biosecurity, particularly where there is movement of seedstock between farms and between farming areas. However, an analysis of biosecurity frameworks for seaweed farming in Indonesia noted that there are major challenges for the implementation of biosecurity in seaweed farming, including unspecific reference to the seaweed aquaculture sector, limited variety of approaches to biosecurity, limited use of up-to-date scientific evidence, insufficient guidance for the use of precaution, and insufficient inclusion of specific biosecurity hazards [94].

Climate change poses a long-term risk to seaweed farming. Increased surface seawater temperatures may have deleterious effects on the reproductive capacity of seaweed, including spore production, germination, recruitment and growth. This may already be contributing to the long-term decline in carrageenan yields discussed above [23]. Increasing water temperature reduces growth rates, photosynthetic performance, phycocolloid quality (carrageenan yield, gel strength and gel viscosity) and pigment (chlorophyll-a, carotenoid and phycobiliproteins) content of Kappaphycus [95]. Stress associated with cultivation in conditions approaching the upper thermal tolerance of seaweed will likely result in increased prevalence of disease outbreaks, including 'ice-ice' [23,95]. The increasing prevalence of typhoons and extreme storm events, arising from more severe El Niño and La Niña weather patterns, is likely to contribute to destruction of seaweed farms [23,95].

One of the main negative personal and social effects of seaweed farming reported in international literature are health impacts [55,56]. Although studies in Indonesia have, to date, found no evidence of negative health impacts from seaweed farming [14], this is a potential personal risk worth monitoring in the future. Potential social risks in terms of spending income on social ills or increases in family violence, although currently not reported [14], should also be monitored.

\subsection{Value Chain and Market Risks}

Neish [11] describes the evolution of carrageenan value chains in Indonesia through four phases, the most recent of which he categorises as a 'relational governance' model. In general, seaweed farmers sell to local (village-based) traders or 'collectors' who on-sell to larger traders (District level), who sell to seaweed processing firms or agents of seaweed processing firms [96]. Seaweed farmers are categorised as either 'independent'(i.e., those who can sell to whichever collector they choose) or 'dependent' (i.e., those who have an established financial relationship with a trader/middleman) [97]. In South Sulawesi, this interdependency may reflect the traditional punggawa-sawi relationship, whereby middlemen (punggawa) provide funding support to enable seaweed farmers (sawi) to establish farms and purchase seedstock [96,98]. A study of 66 seaweed farmers in four Indonesian provinces in 2007-2008 found that 88\% said that they usually sold to the same collector, $59 \%$ sold to independent collectors, and $41 \%$ sold to their cooperative or credit union [11]. Price was cited by $52 \%$ of farmers as a major factor in choosing buyers, $68 \%$ said that the buyer was a friend or relative and $45 \%$ said they had contracts with buyers [11].

The local collectors/traders/collectives, in turn, sell to export traders, of which there are estimated 100 in Indonesia [98]. Export traders may source from seaweed from as few as five to ten suppliers, or as many as 200 [98]. The export traders sell to processors, who are generally specialised for production of either carrageenan or agar. Although multiple 
export traders exist, they are ultimately serving a very limited number of end markets. Four countries-China, Vietnam, Philippines and Korea-accounted for 95\% of Indonesian seaweed exports in 2011 [12], with China alone accounting for $68 \%$.

Despite apparently consistent long-term market growth, seaweed culture may undergo short term 'boom and bust' cycles, typically associated with dramatic price fluctuations. For example, in 2008 the farm-gate price paid for Kappaphycus per tonne of dry product in Indonesia more than doubled, from USD 811 in 2007, to USD 2166, and in 2009 the farm-gate price dropped to USD 1208 per tonne dry weight. In response to these cycles, seaweed farmers often move between seaweed farming and other livelihood activities, such as fishing [10].

The prices of carrageenan seaweed exports to China (the largest export market) appear to be lower but less volatile than other export markets [12]. It is difficult to make general inferences on this pattern because seaweed exports to different markets may not be of the same quality. Nonetheless, industry experts have argued that seaweed buyers from China have been using 'campaign buying' schemes (i.e., concentrating purchases within a short period when the price is low) to lower the cost of their purchases [12]. More recently, the farm-gate prices in Indonesia appeared to stabilise at between USD 550 and 750 per tonne dry product (http: / / www.jasuda.net/, accessed 4 September 2020), before declining again due to COVID-19 impacts on trade [13]. The price paid for seaweed in Indonesia seems to be largely driven by demand from China, which is where the bulk of the processing is carried out [12], and is generally lower than average world prices.

An evaluation of risks in the Indonesian carrageenan supply chain concluded that the most critical risk was the poor quality of raw dried seaweed sent for processing [99]. Factors leading to seaweed quality problems include too rapid harvest of seaweed crops (in as little as 30 days of culture), inadequate drying (moisture levels of $<35 \%$ are generally required by the processors), contamination with sand and other material, and variations in product quality arising from the location, environmental influences and the seaweed cultivar used $[60,99]$. Other critical risks in the carrageenan supply chain which were identified in this study were fluctuations in currency exchange rates, scarcity of raw dried seaweed, and uncertainty of seaweed yields [99]. It is notable that three of the four critical risks identified in this study are associated with farming process and immediate (villagebased) processing, while only one (currency exchange rates) is associated with the broader value chain.

Although some seaweed farmers are organised as collectives/cooperatives [11], such collectives are frequently not well organised, relying heavily on processors and traders for technical assistance, training and financial support [98].

Price instability associated with seasonal supply and demand fluctuations is perceived by seaweed farmers as a major industry sustainability issue [11]. However, the relationships between price, production, and perceived benefits from seaweed farming are complex. Prior to 2008, farm gate prices for carregeenophyte seaweeds had been fairly stable, but, as noted earlier, fluctuated markedly in the period 2008-2009 [11]. Although seaweed farmgate prices declined during the period 2013-2017, this had little or no perceived impact on the satisfaction of seaweed farming households as a major income source [14]. More recently (2019-2020), the farm-gate price for dried Kappaphycus has steadily declined from 19,800 IDR (ca. USD 1.40) to 14,700 IDR (ca. USD 1.05) from January to December 2020 [13]. However, at least in South Sulawesi, there has been an overall increase in the quantity of seaweed produced over the same time span, although, as discussed above, this may be a response to the economic impacts of the COVID-19 pandemic and reduced alternative employment opportunities [13].

The personal and social benefits of seaweed farming perceived by the members of farming households might be due to historic development of the industry, which has been dominated by small-holders and supported by engaged traders [14]. In Indonesia, the industry has very much grown from the 'bottom up', with minimal external 'pushes'. More recently, the Government of Indonesia has set production 'targets' that could be regarded 
as an emerging 'push', with associated supporting regulations and legislation (Table 1). There are some concerns [14] that attempts to further increase seaweed production may lead to increases in large-scale commercial aquaculture ventures that could support more value-added processing in-country. Studies from Indonesia that capture perceptions of personal and social benefits show that seaweed farming in Indonesia is markedly different to seaweed farming in China, Korea and the Philippines, where farms are often owned by large corporations or outsiders, with locals providing poorly paid agricultural labour only [100]. This dichotomy between increasing national production and maintaining the livelihoods of smallholder farmers is not unique to seaweed farming, but has been identified as a critical issue for the future development of aquaculture in Indonesia [10]. Future policy interventions in the seaweed value chain should ideally be designed in a way that builds upon the successes identified to date, ensuring that there are ample opportunities for entire communities to become involved with, and benefit from, industrial scale farming [14].

\section{Creating a Brighter Future for Indonesian Seaweed Farmers}

Seaweed farming supports a large number of rural households in Indonesia, in many cases contributing enough income to lift households out of poverty. The income generated from seaweed farming is valued by the participant households as allowing for spending on transport, housing, fulfilment of basic needs, secondary needs, and university education. However, for seaweed farming to continue to support coastal communities in Indonesia, the risks identified earlier need to be directly addressed by research, development and extension, as well as through policy development.

The economic and social benefits of seaweed farming are recognized by the Indonesian government, which has instituted a range of specific laws and national-level policies government regulations and ministry regulations. Those of direct relevance to seaweed farming are listed in Table 1 with explanatory notes, and additional Ministry of Marine Affairs and Fisheries regulations are listed in Appendix B (Table A1). Of particular import is the Indonesian government's roadmap for seaweed development (government regulation No 33/2019; https:/ / peraturan.bpk.go.id/Home/Details/108806/perpres-no-33-tahun-2019, accessed 25 August 2020) which lists several aspects related to community empowerment, discussed further below.

Table 1. Indonesian laws and regulations directly relevant to seaweed farming and empowerment of seaweed farmers and local communities.

Legislation/Regulations

PERPRES (Peraturan Presiden, Presidential Regulation) No. 33/2019

Road map of seaweed industry

\section{Description}

Several aspects related to community empowerment including:

1 Provision of quality seeds of seaweed from the results of tissue culture and non-tissue culture nurseries/seaweed garden (kebun bibit)

2 Facilitating the labour/manpower in the implementation of cultivation and post-harvest in the seaweed development area

3 Support for the provision of facilities and infrastructure for cultivation and post-harvest seaweed in the cultivation development area.

4 Guidance and quality improvement through post-harvest and processing technical guidance for seaweed cultivators, processors and traders in the main cultivation development areas.

5 Implementation of extension and assistance to cultivators for the best practices of cultivation and post-harvest methods in the seaweed cultivation development areas.

6 Improving the institutional status of seaweed cultivators and processors to become a legal entity.

7 Facilitating groups/cooperatives in access to capital for micro and small-scale cultivation businesses and seaweed processing industries.

8 Facilitating partnerships between industry and cultivators to strengthen the supply of seaweed raw materials.

9 Grow/establish new entrepreneurial and the development of small medium scale enterprises of seaweed processing in seaweed cultivation areas. 
Table 1. Cont.

Legislation/Regulations

Law No. 7/2016 Protection and empowerment of fishermen, fish farmers and salt farmers

\section{Description}

This law is an umbrella of the law/legal guarantee to protect and to empower small-scale fishery communities ( $0.5-5 \mathrm{ha})$ to overcome problems, including threats of disease, contamination, broodstock, seeds, feed and fertilizers, conflicts of coastal land use/land status (land tenure), climate change and also problems of facilities and infrastructure, marketing of products and access to finance

PP (Peraturan Pemerintah) No. $50 / 2015$

The empowerment of smallholder fishermen and small aquaculture

Law No. $1 / 2014$

Management of coastal areas and small islands

(Amendment to law No. 27/2007)
(The implementation of Fishery Law No. 45/2009 \& 31/2004)

Based on this regulation, the Government (National \& Regional level) with their authority are obligated to facilitate finance/capital to the smallholder fishermen and fish farmers
This law guarantees the State's authority and responsibility for the management of the coastal zone and small islands in the form of control over other parties (individual or private) through a licensing mechanism. Granting permission to other parties does not reduce the State's authority to make policies (beleid), make arrangements (regelendaad), carry out administration (bestuursdaad), carry out management (beheersdaad), and carry out supervision (toezichthoudensdaad). Provides rights to communities including customary law community units as well as traditional rights in the principle of the unitary state of the Republic of Indonesia.

Law No. 23/2014

Local government
One of the aspects regulated in this law is the authority of the provincial government to manage marine natural resources except oil and natural gas. Administratively, the Province has the authority to manage the sea to 12 nautical mile limit. However, the limitation of 12 nautical miles does not apply for small-scale fishermen to fishing activities.

The scope of this law includes:

Financing and capital: The national/local government is obliged to facilitate capital assistance or credit schemes for business or operations with a simple method and with a low interest of the loan and by considering the abilities of smallholder fishermen and aquaculture farmers. The sources of financing and capital can come from the APBN/APBD (national/local government budget) or from financing institutions appointed/assigned by the state.

Education, training and extension are organized by the central and local governments to improve the skills of fishermen and aquaculture farmers: The government may cooperate with educational institutions that are certified and appointed by the Minister and also with business operators or the community. Developing groups (fishermen and/or aquaculture farmers) by facilitating the formation of joint business groups (KUB), aquaculture farmer groups (FGs)/(Pokdakan) or fishery cooperatives, and empowering women: In this activity the government provides assistance and provides capital or provides technical and managerial assistance. Empowerment of women is carried out by enhancing the income of the family/conducting fishery and non-fishery businesses, technical and managerial guidance, and increasing the roles of women in planning, implementation, decision-making, monitoring and evaluation. Implementation of activities by smallholders: Small-scale fishermen and aquaculture farmers can carry out their activities in all Indonesian fisheries management areas and get priority to do their activities in conservation areas in sustainable fisheries zones by following the applicable regulations.

Partnership: The Government is obliged to facilitate partnerships between

fishermen and small-scale fish farmers with processors and traders, fishery cooperatives, financial/banking institutions, state/regional and private enterprises

\subsection{Improving Farm Production}

A clearly identified priority within the Indonesian government regulations is the improvement of seaweed farm production in terms of overall biomass productivity, product quality and reliability of production (Table 1). As discussed earlier, the productivity of seaweed farms is influenced by the farm location, seasonal conditions, culture methods, and 
the genetic component of the seaweed stock used [60]. Partitioning these various factors will provide a better understanding of the major factors influencing seaweed productivity on-farm. Our research evaluated production and product quality in Kappaphycus cultivated concurrently at ten locations in Indonesia using identical farming methods, leaving local environmental factors and genetics as the two remaining influential factors, and found a $600 \%$ difference in production and $300 \%$ difference in carrageenan content between locations [60]. Further partitioning of the genetic component of this variability will provide important information for possible improvement in farm production by using seaweed cultivars chosen for improved performance.

Better knowledge of the factors driving seaweed productivity and product quality are essential for mitigating the likely effects of climate change on seaweed farming. Some effects can likely be mitigated by identifying seaweed cultivars that are more resistant to higher water temperatures, and developing new sub-surface cultivation techniques where water temperatures may be lower, such as vertical raft culture [101]. For such culture methods, the trade-off in potential productivity from reduced light availability will need to be balanced against the increased disease risk for shallow lines in the water column.

A long-term decline in carrageenan content is reported for both Kappaphycus and Eucheuma $[8,33,102]$. Future research and development of better-performing seaweed cultivars and policy support for such research, as well as distribution of better-performing cultivars, is essential to halt this trend.

Our study of seaweed mariculture in Sumenep Regency, East Java, identified a number of supply-side problems, including inefficient culture methods and inadequate drying of the harvested seaweed, and noted that most could be resolved using relatively simple interventions [43]. However, resolving these constraints through the provision of effective training and support to seaweed farmers is challenging given the widespread distribution and remote locations of many seaweed farms. The extension systems variously applied by autonomous provincial and District governments are often poorly resourced and undervalued, leading to poor service provision and dissatisfaction amongst both extensionists and farmers [103]. Research into the provision of effective extension and technical support services utilizing new approaches, such as social media, is essential in communicating effectively with seaweed farmers in remote communities throughout the archipelago.

\subsection{Diversifying Market Chains}

The main farmed seaweeds in Indonesia, Kappaphycus, Eucheuma and Gracilaria, are produced for global commodity markets supplying raw materials for food and pharmaceutical products. Consequently, farm-gate prices are subject to the vagaries of supply and demand, both locally and globally. For example, recent declines in the price paid for seaweed in Indonesia may be linked to temporary suspensions of seaweed exports during the COVID-19 pandemic, leading to overstocked storage facilities and falling prices [13]. Increase of in-country industrial processing capacity, supported by both industry and the government, therefore appears to be an important development for future stability.

Diversification of market chains other than carrageenan and agar would assist in reducing the price variation that has been a feature of the carrageenan and agar supply chains. An alternative market chain that is being actively researched is the use of seaweed biomass for agricultural or horticultural fertiliser. The liquid component of Kappaphycus ('sap') has been shown to improve growth and yield in crop plants, and to increase the levels of several micronutrients in the grain, potentially improving its nutritional value $[104,105]$. Similarly, the solid waste component of processed Gracilaria shows potential as an agricultural fertiliser [106]. Further diversification of markets using species of seaweed that are not presently under cultivation may also be possible through integration with livestock in agriculture and aquaculture. Examples include the use of seaweed feed additives (at $3 \%$ or less inclusion) to boost the immune system of fish [107] and to enhance growth and other productivity traits, including reproductive output and stress tolerance [108]. These applications in agriculture and aquaculture would generate new short supply chains with 
national processing and sales of products, whether this be for Indonesian crop production or rabbitfish (Siganus spp.) aquaculture from the examples described above. Current research into the diversification of market chains is very promising, and future research in this area should be expanded.

\subsection{Broadening Benefits to Rural Areas in Indonesia}

The Ministry of Marine Affairs and Fisheries (MMAF) regards mariculture in Indonesia as only $2.3 \%$ exploited, with a potential area of more than 12 million hectares still available for development [9]. Large areas of Indonesia, especially in eastern Indonesia, were still available for seaweed farm development as of late 2009. The less-developed regions included the Java Sea, the Sulawesi Sea, Lesser Sundas (including East Nusa Tenggara), Banda Sea, Halmahera and Papua, but most other regions still had expansion potential as well. If all areas were developed, at least a three-fold increase in Indonesian seaweed production could probably be accomplished [11]. It is notable that many of the areas where seaweed farming could be expanded are amongst the provinces with the highest levels of relative rural poverty in Indonesia, such as East Nusa Tenggara, Gorontalo, Maluku, West Papua and Papua [62]. For the immediate future (2021-2024) MMAF has nominated seaweed as one of its top three priority commodities for aquaculture development in Indonesia (along with shrimp and lobster) and plans expansion of seaweed farming in eastern Indonesia, including in South Sulawesi, East Nusa Tenggara, Maluku, North Maluku and Papua provinces [109].

However, for areal expansion of seaweed farming to be sustainable, current and future constraints need to be addressed, including increased reliability of production, improved farm productivity and product quality, and diversified value chains for a range of seaweed products. Further studies of wellbeing outcomes related to seaweed, in existing seaweed farming regions and the new regions, are recommended. We have also noted previously, and we emphasise here that given topical discussion about the massive industrialisation of seaweed farming for environmental benefits $[28,110]$, any interventions seeking to increase production through large-scale commercial ventures need to consider potential trade-offs with economic and social benefits, specifically for community well-being and regional development [14].

\section{Conclusions}

Seaweed farming is an important and growing form of aquaculture in Indonesia, characterized by significant engagement of smallholders over a wide geographical area. It is of particular relevance to rural coastal communities with limited alternative livelihoods options. Seaweed farming is not technically, financially or labour demanding, and the production cycles are short, providing regular income to the farmers. The benefits obtained are not only financial, but personal and social benefits also accrue to seaweed farming households and communities. There is potential for expansion of seaweed farming to remote coastal and island communities throughout the Indonesian archipelago. Given these characteristics of the industry, it is viewed as a viable option for future betterment of even more coastal communities, and the Indonesian government has implemented a range of laws and regulations to support the industry and its continued development.

However, for seaweed farming to continue to support coastal communities in Indonesia, identified risks to production, value chains and markets need to be addressed through research, development and extension, as well as through policy development. The factors affecting farm productivity and product quality need to be better understood in order to improve the reliability of production and halt, and preferably reverse, the long-term decline in product quality identified for both Kappaphycus and Eucheuma. Because this is likely to involve the development and promulgation of better-performing seaweed cultivars, effective mechanisms for equitable distribution of improved cultivars are necessary, coupled with effective extension and technical support mechanisms. Given the widely distributed nature of seaweed farming in Indonesia, and the remoteness of many farms, 
new and innovative forms of extension will need to be developed. This should include facilitating networking with international experts in specific domains. Additionally, the likely impacts of climate change need to be incorporated into these technical developments.

The Indonesian seaweed value chain would benefit greatly from market diversification. The current model, with production focused on the carrageenan and agar processing industries, leaves producers open to the vagaries of global commodity markets, which causes dramatic fluctuations in seaweed farm-gate prices. Increased in-country industrial processing capacity, supported by both industry and the government, would also improve future price stability and allow additional economic benefits to flow to Indonesia, broadening the socio-economic impacts of seaweed farming.

Author Contributions: Conceptualization, M.A.R., S.L., L.S. and N.A.P.; methodology, M.A.R., S.L., I.L., A.H.P., P.R.P.-M. and L.S.; writing—original draft preparation, M.A.R., S.L. and I.L.; writingreview and editing, M.A.R., S.L., I.L., A.H.P., P.R.P.-M., L.S. and N.A.P.; supervision, N.A.P.; project administration, N.A.P.; funding acquisition, N.A.P., A.H.P. and P.R.P.-M. All authors have read and agreed to the published version of the manuscript.

Funding: This research was funded by the Australian Centre for International Agricultural Research (ACIAR) Project no. FIS/2015/038: 'Improving seaweed production and processing opportunities in Indonesia'.

Institutional Review Board Statement: Not applicable.

Informed Consent Statement: Not applicable.

Data Availability Statement: Not applicable.

Acknowledgments: The authors thank Chris Barlow and Jamalludin Jompa for proposing this review paper. We thank Nur Syamsul (Lukman) for preparing Figure 2 and Suliyanti Hakim for project support and administration in Indonesia.

Conflicts of Interest: The authors declare no conflict of interest.

\section{Appendix A. Income Estimates for Brackishwater Pond Aquaculture}

Economic estimates of seaweed production in brackishwater ponds are few. Laapo and Howara [26] calculated dry seaweed Gracilaria revenue at IDR 132 million (USD 10150) p.a. for a 5.1 ha pond area in Central Sulawesi, compared with IDR 20 million (USD $1540)$ revenue for milkfish in the same polyculture system. This is equivalent to about IDR 26 million (USD 1990) per hectare p.a.

Culture of the edible seaweed Caulerpa in coastal ponds in South Sulawesi ranged from IDR 4.3 (USD 307) to IDR 33 million (USD 2357) per hectare p.a. [29]. Notably, both these estimates are higher than the income that would be expected from 'traditional' shrimp culture in these ponds, which is about IDR 2-10 million (USD 143-714) per hectare p.a. [29]. 


\section{Appendix B. Ministerial Regulations Relating to Seaweed Farming in Indonesia}

Table A1. Ministry of Marine Affairs and Fisheries (Kementrian Kelautan dan Perikanan) regulations Permen (Peraturan Menteri) and Kepmen (Keputusan Menteri) relevant to seaweed farming and farmer and community empowerment.

Legislations/Regulations
MMAF-Permen No. 3/2019: Community participation in implementing the protection and
empowerment of fishermen, fish farmers, and salt farmers (The implementation of Law
No. 7/2016)
MMAF-Permen No.10/2014: Guidelines for implementing the national program for
independently community empowerment for marine and fisheries
MMAF-Permen No. 40/2014: Community participation and empowerment in the management of
coastal areas and small islands
MMAF-Permen No. 31/2014: Guidelines for empowerment of private fisheries extension and
community/self-supporting (swadaya) fisheries extension
MMAF-Kepmen No. 31/2006: Establishment of a community empowerment team for fishermen,
fish farmers and business actors in the marine and fisheries sector

\section{References}

1. Buschmann, A.H.; Camus, C.; Infante, J.; Neori, A.; Israel, Á.; Hernández-González, M.C.; Pereda, S.V.; Gomez-Pinchetti, J.L.; Golberg, A.; Tadmor-Shalev, N.; et al. Seaweed production: Overview of the global state of exploitation, farming and emerging research activity. Eur. J. Phycol. 2017, 52, 391-406. [CrossRef]

2. Naylor, R.L.; Hardy, R.W.; Buschmann, A.H.; Bush, S.R.; Cao, L.; Klinger, D.H.; Little, D.C.; Lubchenco, J.; Shumway, S.E.; Troell, M. A 20-year retrospective review of global aquaculture. Nature 2021, 591, 551-563. [CrossRef]

3. Butcher, H.; Burkhart, S.; Paul, N.; Tiitii, U.; Tamuera, K.; Eria, T.; Swanepoel, L. Role of seaweed in diets of Samoa and Kiribati: Exploring key motivators for consumption. Sustainability 2020, 12, 7356. [CrossRef]

4. Shannon, E.; Abu-Ghannam, N. Seaweeds as nutraceuticals for health and nutrition. Phycologia 2019, 58, 563-577. [CrossRef]

5. Wells, M.L.; Potin, P.; Craigie, J.S.; Raven, J.A.; Merchant, S.S.; Helliwell, K.E.; Smith, A.G.; Camire, M.E.; Brawley, S.H. Algae as nutritional and functional food sources: Revisiting our understanding. J. Appl. Phycol. 2017, 29, 949-982. [CrossRef] [PubMed]

6. Neish, I.C. Good Agronomy Practices for Kappaphycus and Eucheuma: Including an Overview of Basic Biology; SEAPlant.net Monograph no. HB2F 1008 V3 GAP; Seaplant.net Foundation: Makassar, Indonesia, 2008; p. 72.

7. Neish, I.C.; Sepulveda, M.; Hurtado, A.Q.; Critchley, A.T. Reflections on the commercial development of Eucheumatoid seaweed farming. In Tropical Seaweed Farming Trends, Problems and Opportunities; Hurtado, A., Critchley, A., Neish, I., Eds.; Springer: Berlin/Heidelberg, Germany, 2017; Volume 9, pp. 1-27.

8. Porse, H.; Rudolph, B. The seaweed hydrocolloid industry: 2016 updates, requirements, and outlook. J. Appl. Phycol. 2017, 29, 2187-2200. [CrossRef]

9. KKP; JICA. Indonesia Marine and Fisheries Book 2017; Ministry of Marine Affairs and Fisheries and Japan International Cooperation Agency: Tokyo, Japan, 2017; p. 103.

10. Rimmer, M.A.; Sugama, K.; Rakhmawati, D.; Rofiq, R.; Habgood, R.H. A review and SWOT analysis of aquaculture development in Indonesia. Rev. Aquac. 2013, 5, 255-279. [CrossRef]

11. Neish, I.C. Social and economic dimensions of carrageenan seaweed farming in Indonesia. In Social and Economic Dimensions of Carrageenan Seaweed Farming; Fisheries and Aquaculture Technical Paper No. 580; Valderrama, D., Cai, J., Hishamunda, N., Ridler, N., Eds.; Food and Agriculture Organisation of the United Nations: Rome, Italy, 2013; pp. 61-89.

12. Cai, J.; Hishamunda, N.; Ridler, N. Social and economic dimensions of carrageenan seaweed farming: A global synthesis. In Social and Economic Dimensions of Carrageenan Seaweed Farming; Fisheries and Aquaculture Technical Paper No. 580; Valderrama, D., Cai, J., Hishamunda, N., Ridler, N., Eds.; Food and Agriculture Organisation of the United Nations: Rome, Italy, 2013 ; pp. 5-59.

13. Langford, A.; Waldron, S.; Sulfahri; Saleh, H. Monitoring the COVID-19-affected Indonesian seaweed industry using remote sensing data. Mar. Policy 2021, 127, 104431. [CrossRef]

14. Larson, S.; Stoeckl, N.; Fachry, M.E.; Dalvi Mustafa, M.; Lapong, I.; Purnomo, A.H.; Rimmer, M.A.; Paul, N.A. Women's well-being and household benefits from seaweed farming in Indonesia. Aquaculture 2021, 530, 735711. [CrossRef]

15. Cinner, J.E.; McClanahan, T.R.; Graham, N.A.J.; Daw, T.M.; Maina, J.; Stead, S.M.; Wamukota, A.; Brown, K.; Bodin, Ö. Vulnerability of coastal communities to key impacts of climate change on coral reef fisheries. Glob. Environ. Change 2012, 22, 12-20. [CrossRef]

16. Allison, E.H.; Perry, A.L.; Badjeck, M.-C.; Neil Adger, W.; Brown, K.; Conway, D.; Halls, A.S.; Pilling, G.M.; Reynolds, J.D.; Andrew, N.L.; et al. Vulnerability of national economies to the impacts of climate change on fisheries. Fish Fish. 2009, 10, 173-196. [CrossRef]

17. Gallopín, G.C. Linkages between vulnerability, resilience, and adaptive capacity. Glob. Environ. Change 2006, 16, $293-303$. [CrossRef] 
18. Jacob, S.; Weeks, P.; Blount, B.; Jepson, M. Development and evaluation of social indicators of vulnerability and resiliency for fishing communities in the Gulf of Mexico. Mar. Policy 2013, 37, 86-95. [CrossRef]

19. Andréfouët, S.; Dewantama, I.M.I.; Ampou, E.E. Seaweed farming collapse and fast changing socio-ecosystems exacerbated by tourism and natural hazards in Indonesia: A view from space and from the households of Nusa Lembongan island. Ocean Coast. Manag. 2021, 207, 105586. [CrossRef]

20. Davis, M. The Year Bali Tourism Stopped. Available online: https://www.abc.net.au/news/2021-03-09/bali-return-of-seaweedfarming-ceningan-lembongan-penida-covid/13202170 (accessed on 11 May 2021).

21. Costa-Pierce, B.A.; Page, G.G. Aquaculture, Sustainability aquaculture sustainability Science in Aquaculture. In Encyclopedia of Sustainability Science and Technology; Meyers, R.A., Ed.; Springer: New York, NY, USA, 2012; pp. 564-581.

22. Thomsen, M.S.; Wernberg, T.; Engelen, A.H.; Tuya, F.; Vanderklift, M.A.; Holmer, M.; McGlathery, K.J.; Arenas, F.; Kotta, J.; Silliman, B.R. A meta-analysis of seaweed impacts on seagrasses: Generalities and knowledge gaps. PLoS ONE 2012, 7, e28595. [CrossRef] [PubMed]

23. Largo, D.B.; Chung, I.K.; Phang, S.; Gerung, G.S.; Sondak, C.F.A. Impacts of climate change on Eucheuma-Kappaphycus farming. In Tropical Seaweed Farming Trends, Problems and Opportunities; Hurtado, A., Critchley, A., Neish, I., Eds.; Springer: Berlin/Heidelberg, Germany, 2017; Volume 9, pp. 121-129.

24. Kelly, E.L.A.; Cannon, A.L.; Smith, J.E. Environmental impacts and implications of tropical carrageenophyte seaweed farming. Conserv. Biol. 2020, 34, 326-337. [CrossRef] [PubMed]

25. Hehre, E.J.; Meeuwig, J.J. A global analysis of the relationship between farmed seaweed production and herbivorous fish catch. PLoS ONE 2016, 11, e0148250. [CrossRef] [PubMed]

26. Eklöf, J.S.; Henriksson, R.; Kautsky, N. Effects of tropical open-water seaweed farming on seagrass ecosystem structure and function. Mar. Ecol. Prog. Ser. 2006, 325, 73-84. [CrossRef]

27. Eggertsen, M.; Halling, C. Knowledge gaps and management recommendations for future paths of sustainable seaweed farming in the Western Indian Ocean. Ambio 2021, 50, 60-73. [CrossRef] [PubMed]

28. Theuerkauf, S.J.; Morris, J.A., Jr.; Waters, T.J.; Wickliffe, L.C.; Alleway, H.K.; Jones, R.C. A global spatial analysis reveals where marine aquaculture can benefit nature and people. PLOS ONE 2019, 14, e0222282. [CrossRef]

29. Kim, J.; Stekoll, M.; Yarish, C. Opportunities, challenges and future directions of open-water seaweed aquaculture in the United States. Phycologia 2019, 58, 446-461. [CrossRef]

30. Gentry, R.R.; Alleway, H.K.; Bishop, M.J.; Gillies, C.L.; Waters, T.; Jones, R. Exploring the potential for marine aquaculture to contribute to ecosystem services. Rev. Aquac. 2020, 12, 499-512. [CrossRef]

31. Campbell, I.; Macleod, A.; Sahlmann, C.; Neves, L.; Funderud, J.; Øverland, M.; Hughes, A.D.; Stanley, M. The environmental risks associated with the development of seaweed farming in Europe-prioritizing key knowledge gaps. Front. Mar. Sci. 2019, 6, 107. [CrossRef]

32. Alleway, H.K.; Gillies, C.L.; Bishop, M.J.; Gentry, R.R.; Theuerkauf, S.J.; Jones, R. The ecosystem services of marine aquaculture: Valuing benefits to people and nature. BioScience 2019, 69, 59-68. [CrossRef]

33. Ask, E.I.; Azanza, R.V. Advances in cultivation technology of commercial eucheumatoid species: A review with suggestions for future research. Aquaculture 2002, 206, 257-277. [CrossRef]

34. Ratnawati, P.; Simatupang, N.F.; Pong-Masak, P.R.; Paul, N.A.; Zuccarello, G.C. Genetic diversity analysis of cultivated Kappaphycus in Indonesian seaweed farms using COI gene. Squalen Bull. Mar. Fish. Postharvest Biotechnol. 2020, 15, 65-72. [CrossRef]

35. Sulistiani, E.; Soelistyowati, D.T.; Alimuddin; Yani, S.A. Callus induction and filaments regeneration from callus of cottoni seaweed (Kappaphycus alvarezii (Doty)) collected from Natuna Islands, Riau Islands Province. Biotropia 2012, 19, 103-114. [CrossRef]

36. FAO Fishery and Aquaculture Statistics. Global Aquaculture Production 1950-2019 (FishstatJ). FAO Fisheries Division, FAO Fisheries and Aquaculture Department, FIPS—Statistics and Information: Rome, Italy, 2021. Updated 2021. 2.0.0. Available online: www.fao.org/fishery/statistics/software/fishstatj/en (accessed on 15 May 2021).

37. Adhawati, S.S.; Fudjaja, L. Analysis productivity of seaweed cultivation (Glacilaria. sp) in Takalar Regency, South Sulawesi. IOP Conf. Ser. Earth Environ. Sci. 2020, 492, 012121. [CrossRef]

38. Necas, J.; Bartosikova, L. Carrageenan: A review. Vet. Med. 2013, 58, 187-205. [CrossRef]

39. Armisen, R. World-wide use and importance of Gracilaria. J. Appl. Phycol. 1995, 7, 231-243. [CrossRef]

40. McHugh, D.J. A Guide to the Seaweed Industry; FAO Fisheries Technical Paper No.441; Food and Agriculture Organisation of the United Nations: Rome, Italy, 2003; p. 105.

41. Bixler, H.; Porse, H. A decade of change in the seaweed hydrocolloids industry. J. Appl. Phycol. 2010, 23, 321-335. [CrossRef]

42. Mustafa, A.; Sammut, J. Dominant factors affecting seaweed (Gracilaria verrucosa) production in acid sulfate soils-affected ponds of Luwu Regency, Indonesia. Indones. Aquac. J. 2010, 5, 147-162. [CrossRef]

43. Purnomo, A.H.; Kusumawati, R.; Pratitis, A.; Alimin, I.; Wibowo, S.; Rimmer, M.; Paul, N. Improving margins of the Indonesian seaweed supply chain upstream players: The application of the kaizen approach. E3S Web Conf. 2021, 226, 00004. [CrossRef]

44. Malik, A.; Mertz, O.; Fensholt, R. Mangrove forest decline: Consequences for livelihoods and environment in South Sulawesi. Reg. Environ. Change 2017, 17, 157-169. [CrossRef]

45. Laapo, A.; Howara, D. Coastal community welfare improvement through optimization of integrated pond farming management in Indonesia. Int. J. Agric. Syst. 2016, 4, 73-84. [CrossRef] 
46. Arbit, N.I.S.; Omar, S.B.A.; Soekendarsi, E.; Yasir, I.; Tresnati, J.; Mutmainnah; Tuwo, A. Morphological and genetic analysis of Gracilaria sp. cultured in ponds and coastal waters. In Proceedings of the 2nd International Symposium on Marine Science and Fisheries (ISMF2), IOP Conference Series: Earth and Environemental Science, Makassar, Indonesia, 22 June 2019; Volume 370, p. 012018.

47. Lapong, I.; Paul, N.; Reza, A. Characterization of sea grapes (Caulerpa lentillifera) from Vietnamese company's products. Mar. Chim. Acta 2019, 20, 51-57. [CrossRef]

48. Putra, N.S.S.U.; Lapong, I.; Rimmer, M.A.; Raharjo, S. Caulerpa culture in South Sulawesi-An alternative for brackishwater pond culture. Aquac. Asia-Pac. 2013, 9, 44-45.

49. Perryman, S.E.; Lapong, I.; Mustafa, A.; Sabang, R.; Rimmer, M.A. Potential of metal contamination to affect the food safety of seaweed (Caulerpa spp.) cultured in coastal ponds in Sulawesi, Indonesia. Aquac. Rep. 2017, 5, 27-33. [CrossRef]

50. Shafitri, N.; Zulham, A.; Muawanah, U. Social structure of seaweed farmers in border areas: Cases in seaweed farmers in Nunukan Island. IOP Conf. Ser. Earth Environ. Sci. 2019, 348, 012053. [CrossRef]

51. Rahim, M.; Aslan, L.O.M.; Ruslaini; Taridala, S.A.A.; Wianti, N.I.; Nikoyan, A.; Budiyanto; Hafid, H. Livelihood features of seaweed farming households: A case study from Bungin Permai Village, South Konawe, South East (SE) Sulawesi, Indonesia. IOP Conf. Ser. Earth Environ. Sci. 2019, 370, 012025. [CrossRef]

52. Tahang, H.; Latama, G.; Kasri. Development strategy and increased production of seaweed in Takalar District. IOP Conf. Ser. Earth Environ. Sci. 2019, 370, 012058. [CrossRef]

53. Busthanul, N.; Diansari, P.; Summase, I.; Amiruddin, A.; Lanuhu, N.; Viantika, N.M.; Yusuf, S.; Permadi, M.G. Agribusiness development economic study of seaweed. IOP Conf. Ser. Earth Environ. Sci. 2019, 343, 012110. [CrossRef]

54. Tawakal, M.A.; Siman, S.; Djanggo, R.T.P.M.; Unde, A.A. Analysis of the benefits of seaweed farming and its effects on the environment and community activities (study in the city of Tual, Southeast Maluku). IOP Conf. Ser. Earth Environ. Sci. 2019, 343, 012187. [CrossRef]

55. Food and Agriculture Organisation. Women's Empowerment in Aquaculture in Bangladesh and Indonesia: Insights from Four Case Studies; Food and Agriculture Organisation of the United Nations: Rome, Italy, 2017; p. 4.

56. Fröcklin, S.; de la Torre-Castro, M.; Lindström, L.; Jiddawi, N.S.; Msuya, F.E. Seaweed mariculture as a development project in Zanzibar, East Africa: A price too high to pay? Aquaculture 2012, 356-357, 30-39. [CrossRef]

57. Blankenhorn, S.U. Seaweed Farming and Artisanal Fisheries in an Indonesian Seagrass Bed-Complementary or Competitive Usages? Ph.D. Thesis, Bremen University, Bremen, Germany, 2007; p. 118.

58. Theuerkauf, S.J.; Barrett, L.T.; Alleway, H.K.; Costa-Pierce, B.A.; St. Gelais, A.; Jones, R.C. Habitat value of bivalve shellfish and seaweed aquaculture for fish and invertebrates: Pathways, synthesis and next steps. Rev. Aquac. 2021. [CrossRef]

59. Mariño, M.; Breckwoldt, A.; Teichberg, M.; Kase, A.; Reuter, H. Livelihood aspects of seaweed farming in Rote Island, Indonesia. Mar. Policy 2019, 107, 103600. [CrossRef]

60. Simatupang, N.F.; Pong-Masak, P.R.; Ratnawati, P.; Agusman; Paul, N.A.; Rimmer, M.A. Growth and product quality of the seaweed Kappaphycus alvarezii from different farming locations in Indonesia. Aquac. Rep. 2021, 20, 100685. [CrossRef]

61. Aslan, L.O.M.; Supendy, R.; Taridala, S.A.A.; Hafid, H.; Sifatu, W.O.; Sailan, Z.; Niampe, L. Income of seaweed farming households: A case study from Lemo of Indonesia. IOP Conf. Ser. Earth Environ. Sci. 2018, 175, 012221. [CrossRef]

62. OECD. OECD Development Pathways, Social Protection System Review of Indonesia. Available online: https://www.oecdilibrary.org/sites/3860c253-en/index.html?itemId=/content/component/3860c253-en (accessed on 11 August 2019).

63. Valderrama, D.; Cai, J.; Hishamunda, N.; Ridler, N.; Neish, I.C.; Hurtado, A.Q.; Msuya, F.E.; Krishnan, M.; Narayanakumar, R.; Kronen, M.; et al. The economics of Kappaphycus seaweed cultivation in developing countries: A comparative analysis of farming systems. Aquac. Econ. Manag. 2015, 19, 251-277. [CrossRef]

64. Moglia, M.; Alexander, K.S.; Larson, S.; Giger-Dray, A.; Greenhalgh, G.; Thammavong, P.; Thephavanh, M.; Case, P. Gendered roles in agrarian transition: A study of lowland rice farming in Lao PDR. Sustainability 2020, 12, 5403. [CrossRef]

65. Greenhalgh, G.; Alexander, K.S.; Larson, S.; Thammavong, P.; Sacklokham, S.; Thephavanh, M.; Sinavong, P.; Moglia, M.; Perez, P.; Case, P. Transdisciplinary agricultural research in Lao PDR. J. Rural Stud. 2019, 72, 216-227. [CrossRef]

66. Diansari, P.; Rukmana, D.; Nadja, R.A.; Rahmadanih; Fahmid, I.M.; Syahrullah. Analysis of the contribution of income in fulfilling household livelihoods of coastal communities. IOP Conf. Ser. Earth Environ. Sci. 2020, 486, 012015. [CrossRef]

67. Zamroni, A.; Laoubi, K.; Yamao, M. The development of seaweed farming as a sustainable coastal management method in Indonesia: An opportunities and constraints assessment. WIT Trans. Ecol. Environ. 2011, 150, 505-516. [CrossRef]

68. Hassan, R.; Scholes, R.; Ash, N. Ecosystems and Human Well-Being: Current State and Trends; Island Press: Washington, DC, USA, 2005.

69. Jarvis, D.; Stoeckl, N.; Liu, H.-B. New methods for valuing, and for identifying spatial variations, in cultural services: A case study of the Great Barrier Reef. Ecosyst. Serv. 2017, 24, 58-67. [CrossRef]

70. Larson, S. Regional well-being in tropical Queensland, Australia: Developing a dissatisfaction index to inform government policy. Environ. Plan. 2010, 42, 2972-2989. [CrossRef]

71. Li, Q.; Stoeckl, N.; King, D. Using the life-satisfaction approach to quantify the complex inter-related impacts of coal mining on host communities: A case study in Shanxi, China. Resour. Policy 2019, 62, 305-316. [CrossRef]

72. Stoeckl, N.; Hicks, C.; Farr, M.; Grainger, D.; Esparon, M.; Thomas, J.; Larson, S. The crowding out of complex social goods. Ecol. Econ. 2018, 144, 65-72. [CrossRef] 
73. Smith, C.L.; Clay, P.M. Measuring subjective and objective well-being: Analyses from five marine commercial fisheries. Hum. Organ. 2010, 69, 158-168. [CrossRef]

74. Allison, E.H.; Ellis, F. The livelihoods approach and management of small-scale fisheries. Mar. Policy 2001, 25, 377-388. [CrossRef]

75. D'Anna, L.M.; Murray, G.D. Perceptions of shellfish aquaculture in British Columbia and implications for well-being in marine social-ecological systems. Ecol. Soc. 2015, 20, 57. [CrossRef]

76. Himes-Cornell, A.; Kasperski, S. Using socioeconomic and fisheries involvement indices to understand Alaska fishing community well-being. Coast. Manag. 2016, 44, 36-70. [CrossRef]

77. Diener, E.; Suh, E.M.; Lucas, R.E.; Smith, H.L. Subjective well-being: Three decades of progress. Psychol. Bull. 1999, 125, $276-302$. [CrossRef]

78. Alkire, S. Valuing Freedoms: Sen's Capability Approach and Poverty Reduction; Oxford University Press: Oxford, UK, $2002 ;$ p. 352.

79. Millennium Ecosystem Assessment. Ecosystems and Human Well-Being: A Framework for Assessment; Island Press: Washington, DC, USA, 2003; p. 245.

80. Diener, E.; Suh, E. Measuring quality of life: Economic, social, and subjective indicators. Soc. Indic. Res. 1997, 40, 189-216. [CrossRef]

81. Max-Neef, M. Economic growth and quality of life: A threshold hypothesis. Ecol. Econ. 1995, 15, 115-118. [CrossRef]

82. Söderbaum, P. Ecological Economics: Political Economics for Social and Environmental Development; Earthscan: London, UK, 2000; p. 152.

83. Pollnac, R.B.; Crawford, B.R.; Rotinsulu, C. Final Documentation and Assessment of the Coastal Resources Management Project Community-Based Sites of Talise, Blongko, Bentenan and Tumbak in the District of Minahasa, North Sulawesi Province, Indonesia; University of Rhode Island, Coastal Resources Center: Narragansett, RI, USA, 2003; p. 104.

84. Larson, S.; Stoeckl, N.; Rimmer, M.A.; Paul, N.A. Understanding feedback relationships between resources, functionings and well-being: A case study of seaweed farming and artisanal processing in Indonesia. Ambio 2021. [CrossRef]

85. Larson, S.; Stoeckl, N.; Jarvis, D.; Addison, J.; Prior, S.; Esparon, M. Using measures of wellbeing for impact evaluation: Proof of concept developed with an Indigenous community undertaking land management programs in northern Australia. Ambio 2019, 48, 89-98. [CrossRef]

86. Ganesan, A.R.; Tiwari, U.; Rajauria, G. Seaweed nutraceuticals and their therapeutic role in disease prevention. Food Sci. Hum. Wellness 2019, 8, 252-263. [CrossRef]

87. Nielsen, C.W.; Rustad, T.; Holdt, S.L. Vitamin C from seaweed: A review assessing seaweed as contributor to daily intake. Foods 2021, 10, 198. [CrossRef]

88. Swanepoel, L.; Tioti, T.; Eria, T.; Tamuera, K.; Tiitii, U.; Larson, S.; Paul, N. Supporting women's participation in developing a seaweed supply chain in Kiribati for health and nutrition. Foods 2020, 9, 382. [CrossRef]

89. Williams, B.; Mancia, G.; Spiering, W.; Agabiti Rosei, E.; Azizi, M.; Burnier, M.; Clement, D.L.; Coca, A.; de Simone, G.; Dominiczak, A.; et al. 2018 ESC/ESH Guidelines for the management of arterial hypertension: The Task Force for the management of arterial hypertension of the European Society of Cardiology (ESC) and the European Society of Hypertension (ESH). Eur. Heart J. 2018, 39, 3021-3104. [CrossRef]

90. United States Department of Agriculture; United States Department of Health and Human Services. Dietary Guidelines for Americans, 7th ed.; Government Printing Office: Washington, DC, USA, 2010.

91. Umemura, S.; Arima, H.; Arima, S.; Asayama, K.; Dohi, Y.; Hirooka, Y.; Horio, T.; Hoshide, S.; Ikeda, S.; Ishimitsu, T.; et al. The Japanese Society of Hypertension Guidelines for the Management of Hypertension (JSH 2019). Hypertens. Res. 2019, 42, 1235-1481. [CrossRef]

92. Prein, M.; Ahmed, M. Integration of aquaculture into smallholder farming systems for improved food security and household nutrition. Food Nutr. Bull. 2000, 21, 466-471. [CrossRef]

93. Ward, G.M.; Faisan, J.P., Jr.; Cottier-Cook, E.J.; Gachon, C.; Hurtado, A.Q.; Lim, P.E.; Matoju, I.; Msuya, F.E.; Bass, D.; Brodie, J. A review of reported seaweed diseases and pests in aquaculture in Asia. J. World Aquac. Soc. 2020, 51, 815-828. [CrossRef]

94. Kambey, C.S.B.; Campbell, I.; Sondak, C.F.A.; Nor, A.R.M.; Lim, P.E.; Cottier-Cook, E.J. An analysis of the current status and future of biosecurity frameworks for the Indonesian seaweed industry. J. Appl. Phycol. 2020, 32, 2147-2160. [CrossRef]

95. Kumar, Y.N.; Poong, S.-W.; Gachon, C.; Brodie, J.; Sade, A.; Lim, P.-E. Impact of elevated temperature on the physiological and biochemical responses of Kappaphycus alvarezii (Rhodophyta). PLoS ONE 2020, 15, e0239097. [CrossRef] [PubMed]

96. Zamroni, A.; Yamao, M. An assessment of farm-to-market link of Indonesian dried seaweeds: Contribution of middlemen toward sustainable livelihood of small-scale fishermen in Laikang Bay. Afr. J. Agric. Res. 2012, 7, 4198-4208. [CrossRef]

97. Mulyati, H.; Geldermann, J.; Kusumastanto, T. Carrageenan supply chains in Indonesia. IOP Conf. Ser. Earth Environ. Sci. 2020, 414, 012013. [CrossRef]

98. Saleh, H.; Sebastian, E. Seaweed Nation: Indonesia's New Growth Sector; Backgrounder April 2020, No. 02/2020; Australia-Indonesia Centre: Caulfield East, VIC, Australia, 2020; p. 18.

99. Mulyati, H.; Geldermann, J. Managing risks in the Indonesian seaweed supply chain. Clean Technol. Environ. Policy 2017, 19, 175-189. [CrossRef]

100. Hurtado, A.Q.; Neish, I.C.; Critchley, A.T. Developments in production technology of Kappaphycus in the Philippines: More than four decades of farming. J. Appl. Phycol. 2015, 27, 1945-1961. [CrossRef] 
101. Pong-Masak, P.R.; Sarira, N.H. Penentuan jarak tanam optimal antar rumpun bibit pada metode vertikultur rumput laut (Determination of optimal planting distance between seed clump on seaweed verticulture method. J. Perikan. Univ. Gadjah Mada 2018, 21, 23-30. [CrossRef]

102. Hurtado, A.Q.; Neish, I.C.; Critchley, A.T. Phyconomy: The extensive cultivation of seaweeds, their sustainability and economic value, with particular reference to important lessons to be learned and transferred from the practice of eucheumatoid farming. Phycologia 2019, 58, 472-483. [CrossRef]

103. Herianto, A.S.; Wastutinigsih, S.P.; Foster, D.; Rimmer, M.; Callinan, R. Agricultural and fisheries extension in Indonesia-Origins, transitions and current challenges. Ext. Farming Syst. J. 2010, 6, 23-31.

104. Layek, J.; Das, A.; Ghosh, A.; Sarkar, D.; Idapuganti, R.G.; Boragohain, J.; Yadav, G.S.; Lal, R. Foliar application of seaweed sap enhances growth, yield and quality of maize in Eastern Himalayas. Proc. Natl. Acad. Sci. USA 2019, 89, 221-229. [CrossRef]

105. Begum, M.; Bordoloi, B.C.; Singha, D.D.; Ojha, N.J. Role of seaweed extract on growth, yield and quality of some agricultural crops: A review. Agric. Rev. 2018, 39, 321-326. [CrossRef]

106. Basmal, J.; Munifah, I.; Rimmer, M.; Paul, N. Identification and characterization of solid waste from Gracilaria sp. extraction. IOP Conf. Ser. Earth Environ. Sci. 2019, 404, 012057. [CrossRef]

107. Thépot, V.; Campbell, A.H.; Paul, N.A.; RImmer, M.A. Seaweed dietary supplements enhance the innate immune response of the mottled rabbitfish Siganus fuscescens. Fish Shellfish Immunol. 2021, 113, 176-184. [CrossRef] [PubMed]

108. Thépot, V.; Campbell, A.H.; Rimmer, M.A.; Paul, N.A. Effects of a seaweed feed inclusion on different life stages of the mottled rabbitfish Siganus fuscescens. Aquac. Res. 2021. [CrossRef]

109. Soebjakto, S. Strategi Peningkatan Produksi dan Lokasi Kampung Budidaya Perikanan Tahun 2021 (Production Improvement Strategy and Location of Aquaculture Villages 2021). In Presentation to Technical Work Meeting (Rakernis), Agency for Marine and Fisheries Research and Human Resources; Ministry of Marine Affairs and Fisheries: Bandung, India, 2021; 30p.

110. Laurens, L.M.L.; Lane, M.; Nelson, R.S. Sustainable seaweed biotechnology solutions for carbon capture, composition, and deconstruction. Trends Biotechnol. 2020, 38, 1232-1244. [CrossRef] 